\title{
Superoxide Dismutase [Mn], Mitochondrial
}

National Cancer Institute

\section{Source}

National Cancer Institute. Superoxide Dismutase [Mn], Mitochondrial. NCI Thesaurus.

Code C16819.

Superoxide dismutase [Mn], mitochondrial (222 aa, $25 \mathrm{kDa}$ ) is encoded by the human SOD2 gene. This protein plays a role in superoxide reduction. 